\title{
Лiтература:
}

1. Греков В. П., Бзот В. Б., Кужель І. С., Шигімага Н. В. Оцінка впливу дій сил та засобів розвідки на ефективність застосування ракетного комплексу з урахуванням характеристик озброєння сторін. Збірник наукових праџь Харківського наџіонального університету Повітряних Сил. 2019. № 3(61). С. 12-17. https://doi.org/10.30748/ zhups.2019.61.02.

2. Додонов А. Г., Никифоров А. В., Путятин В. Г. Концепция автоматизации процесса организационного управления ракетной бригадой, вооружённой оперативно-тактическим ракетным комплексом. Збірник наукових праџь Харківського наџіонального університету Повітряних Сил. 2018. № 3(57). С. 43-56. https://doi.org/10.30748/ zhups.2018.57.07.

3. Загорка О. М. Коваль В. В., Загорка І. О. Методичні положення оцінки живучості зенітної ракетної системи від дії по іiї елементах засобів ураження противника. Збірник наукових пращь Харківського національного університету Повітряних Сил. 2017. № 4(53). С. 13-16.

DOI https://doi.org/10.30525/978-9934-588-79-2-2.50

\section{ТЕОРЕТИЧНІ АСПЕКТИ РОЗРОБКИ ІНТЕЛЕКТУАЛЬНИХ СКЛАДОВИХ ДЛЯ ФОРМУВАННЯ УПРАВЛІНСЬКИХ РІШЕНЬ 3 ОХОРОНИ ПРАЦІ НА ПІДПРИЕМСТВІ}

\author{
Сірик А. О. \\ кандидат технічних наук, \\ доцент кафедри екологічної безпеки та охорони праці \\ Начіонального університету харчових технологій \\ м. Київ, Украӥна
}

Мета даної роботи - обгрунтувати необхідність розробки та впровадження в практику промислових підприємств концепції «Інтелектуалізації системи управління охороною праці» на основі роботи інтелектуальних складових, що являє собою симбіоз ключових понять сучасності - інновацій та інтелекту, ефект яких є запорукою підвищення профілактики виробничого травматизму, адже ефективність функціонування будь-якої системи управління виражається в результативності функціонування об’єкта управління. 
Однією з характерних рис сучасного етапу економічного розвитку суспільства $\epsilon$ широке впровадження засобів комп'ютерної техніки для вирішення різноманітних завдань управління [1]. Вирішення завдання управління охороною праці полягає у розробленні управлінського рішення з подальшим втіленням у роботу підприємства.

В сучасних умовах, однією 3 характерних рис функціонування промислових підприємств $\epsilon$ його існування в умовах невизначеності і постійних змін. Підвищення рівня безпеки промислового виробництва тягне за собою значні капіталовкладення на його переоснащення, перенавчання персоналу. Визначні фактори: створення і розробка механізмів ефективного управління в умовах змін і створена на їх основі організаційна структура підприємства - введення інтелектуальної складової, дозволять постійно підтримувати його високу продуктивність та безаварійну роботу.

У сучасних системах оперативного управління охороною праці передбачається створення як математичного так і програмного забезпечення систем прийняття рішень і баз даних; порядок збору, обробки, аналізу та використання даних в процесі здійснення управлінської діяльності. Орієнтація на застосування мережевих технологій є однією 3 умов ефективного функціонування та розвитку систем оперативного управління охороною праці [2].

Для того, щоб утримати позиції лідера, недостатньо використовувати стандартний менеджерський набір інструментів, необхідно взяти на озброєння так званий інноваційний підхід, суттю якого є використання інтелектуальних інструментів управління. Одним 3 таких управлінських інноваційних інструментів може стати розробка інтелектуальних складових для формування управлінських рішень 3 впровадженням інформаційно-аналітичної системи управління охороною праці на підприємстві.

Одним 3 перспективних наукових напрямків $є$ використання мультиагентних технологій (використання інтелектуального агента) в інформаційно-аналітичних системах сучасних технологічних підприємств, що дозволить керівнику ефективно використовувати різні сукупності заходів в рамках загальної множини нормативно-правових документів для підвищення рівня безпеки праці [4].

На сьогоднішній день на передній план наукових досліджень висувається завдання підвищення рівня інтелектуальності спеціалізованих керуючих систем, яка витікає з обмеженості традиційного інформаційного підходу. В рамках загальної концепції побудови інформаційно-аналітичної системи технологічних підприємств сформульовано 
агентно-орієнтований підхід до інтелектуальної взаємодії компонентів. В якості моделі інтелектуального агента пропонується наступний варіант пошуку рішення: вважаємо, що інтелектуальний агент має визначену множину статичних цілей $G S=\left\{g s^{i} \mid i=1, \ldots, n\right\}$. Апріорі відомі шляхи досягнення цілей, тобто побудовані інформаційні об'єкти $\left(I O^{i} \mid i=1, \ldots, n\right)$, функціонування яких повинне вести до $g s^{i}$. Тут кожен інформаційний об'єкт покриває деякий план. Усередині ж цього плану, тобто в моделі поведінки інформаційного агента, можуть бути сформовані довільні повідомлення і довільні послідовності дій.

Тоді модель пошуку рішення задається функцією пошуку рішення $S R: G S \rightarrow V O$ де $V O$ - множина вкладених інформаційних об'єктів і-го інтелектуального агента. Це відображення однозначне, але не взаємно, оскільки можливо, що декілька цілей досягаються одним і тим же інформаційним об'єктом. Модель активних дій визначається відображенням $A D: G A \rightarrow V O$, яке вибирає необхідні для запуску у нинішній момент інформаційний об'єкт [3].

Побудована модель пошуку рішення в узагальненій моделі інтелектуального агента інформаційно-аналітичної системи управління охороною праці дозволяє описати такі відомі класи моделей реалізації поведінки як моделі із зумовленою кінцевою множиною елементарних дій; моделі з множиною планів; моделі з довільними повідомленнями і діями. На базі даної моделі можуть створюватися нові моделі реалізації поведінки інтелектуальних агентів, що поєднують механізми різних класів.

Ефективність будь-якої системи управління виражається в результативності функціонування об'єкту управління. При аналізі ефективності системи управління охороною праці промислових підприємств показниками іï функціонування $є$ ефективне використання системи підтримки прийняття рішень, що враховує вимоги нормативноправових актів з охорони праці та параметри шкідливих та небезпечних факторів на робочих місцях працівників харчового підприємства. Поєднання показників для роботи інтелектуального агента ті інформаційного об'єкта інформаційно-аналітичної системи підприємства дозволяє оцінити стан безпеки праці і є підставою для розробки заходів щодо покращення умов праці та попередженню виробничого травматизму.

На основі узагальненої моделі інтелектуального агента на базі однієї і тієї ж інтелектуальної інформаційно-аналітичної системи управління охороною праці можна досліджувати і створювати різноманітні системи, які включають інтелектуальні агенти [4]. 
Формування управлінських рішень має базуватись на комплексному використанні баз даних про виробничий травматизм та наглядову діяльність, методів математичного моделювання, прогнозування та експертних оцінок [1].

Впровадження нових моделей та принципів у інформаційному забезпеченні охорони праці із залученням сучасних інформаційноаналітичних та систем з інтелектуальними складовими відіграє вирішальну роль у обгрунтованості та своєчасності прийнятих управлінських рішень.

\section{Література:}

1. Кружилко О. Є., Майстренко В. В., Демчук Г. В., Полукаров О. І. Удосконалення оперативного управління охороною праці. Проблеми охорони праичі в Украйні. 2016. Вип. 32. С. 37-42.

2. Кружилко О. Є., Майстренко В. В., Полукаров О. I., Демчук Г. В. Оцінка ефективності управлінських рішень у сфері охорони праці. Проблеми охорони праці в Україні. 2015. Вип. 29. С. 3-9.

3. Сірик А.О. Моделі та методи підвищення рівня безпеки праці в енергетичному господарстві підприємств харчової промисловості на основі використання системи підтримки прийняття рішень: автореф. дис. ... канд. техн. наук: 05.26.01 / ДУ «ННДІПБОП». Київ, 2018. 20 с.

4. Євтушенко О. В., Сірик А. О. Побудова моделі інтелектуального агента для інформаційно-керуючої системи енергетичного господарства підприємств харчової промисловості. Наукові пращі Наџіонального університету харчових технологій. 2016. Т. 22, № 5. C. $113-119$. 